\title{
Adding Value to a Scottish Rye Landrace: Collaborative Research into New Artisanal Products
}

\author{
Stan Blackley, David McVey, Maria Scholten, \\ and Adam Veitch
}

Abstract Hebridean rye (Secale cereale), a high-yield landrace grown by
crofters in Scotland's Highlands and Islands, has traditionally been used as

The project is an output of Crofters Diversity Pays! (CDP), a partnership involving the Scottish Crofting Federation, Queen Margaret University, Edinburgh and Science and Advice for Scottish Agriculture (SASA), funded by the European Social Innovation Funds and the Scottish Government under project number SIF-R5-S2-HI-004.

S. Blackley $(\bowtie) \cdot$ D. McVey

Queen Margaret University, Edinburgh, UK

e-mail: sblackley@qmu.ac.uk

M. Scholten

Scottish Crofting Federation, Kyle of Lochalsh, UK

A. Veitch

Doughies Bakery, Fort William, UK

(C) The Author(s) 2022

Y. Nishikawa and M. Pimbert (eds.), Seeds for Diversity and Inclusion, https://doi.org/10.1007/978-3-030-89405-4_9 
livestock feed. This multi-author study presents and analyses findings into the crop's potential as the raw material for locally produced flour, bread and beer, offering new opportunities in sustainable seed saving, smallscale agriculture, food production and eco-enterprise. The authors-part of the project's multidisciplinary team of researchers, artisanal food producers and crofters - explicate aspects of the pioneering project, from conditions on Uist's coastal machair where the rye originates, to testing seasonal varieties in mainland Lochaber and assessing nutritional qualities and consumer acceptance of novel products. They conclude that Hebridean rye, with its potential for crofters in remote locales and local businesses, could help in preserving agrobiodiversity, traditional knolwedge and practices, crofting culture and economic resilience in the north and north-west of Scotland.

Keywords Artisanal products - Collaborative research - Economic resilience $\cdot$ Rye landraces $\cdot$ Scottish crofters

\subsection{INTRODUCTION}

This chapter describes a project exploring the potential for adding value to the landrace, Hebridean rye (Secale cereale) by finding new culinary and food-related uses for it, with a view to reintroducing it to the mainland Highlands of Scotland for cultivation. Hebridean rye was traditionally grown in Scotland's Highlands and Islands - the mainland Highlands, along with Orkney, Shetland and the Outer Hebrides-but is currently restricted to the Outer Hebridean islands.

Hebridean rye is a component of a livestock feed mixture valued for its local adaptation and good yields under extreme conditions. It is cultivated by crofters, who work small landholdings, or crofts, that are unique to Scotland, and deploy low-input practices. Cereal cultivation on islands can be viewed as a unique form of agricultural biodiversity, connecting traditional and cultural practices with place-specific land management processes. As cultivation of the rye has reduced in the Highlands, the traditional knowledge and agricultural systems linked to it are being lost.

This multipartite and interdisciplinary research was therefore significant. Moreover, a team of researchers and artisanal food producers was put in place to assess the landrace's potential for novel uses. Inspired by seed and food sovereignty values, the project sought to explore new opportunities for and with crofters to cultivate the rye for use in new food 
and drink products such as flour, bread and beer. These types of opportunities are vital to the preservation of crofting life, and to support young crofters in turning the demographic tide in the Outer Hebrides where the population is ageing.

Uist in the Outer Hebrides, a group of six islands, is one of the few areas in Scotland and the United Kingdom with surviving landraces. There are written records for their production dating back to the seventeenth century (Martin, 1703). To this day, a mix of barley, oats and rye are still grown as 'crofters' corn', used as animal feed.

The endurance of this traditional cereal mixture may in part be due to the unique conditions of the machair - the unique coastal flatlands habitat where the crop is grown. Highly alkaline soils block the uptake of essential nutrients, such as manganese, by crops, leaving them prone to disease and stunted growth and there are currently no commercial cereal varieties on the market in Britain that can cope with these extreme conditions without additional spraying with manganese, yet the local landraces are able to yield without this intervention due to local adaptation (Schmidt et al., 2019). The machair is also protected by a number of environmental designations and restrictions, which can disallow the requirement to apply manganese spray on 'non-island varieties'. This combination of factors makes the native landraces the most economical to cultivate. The Hebridean rye landrace is therefore a 'crofters' landrace'.

\subsection{Seed Sources and Seed Governance IN THE HIGHLANDS AND ISLANDS}

With the islands of Uist entirely self-reliant on locally produced seed in a low-input agricultural system, seed governance here can be seen as an informal seed system, or perhaps more accurately, ad hoc seed supply chains without formal organisation or central point, in other words, a 'spontaneous order' (Ward, 1988) based on values of crofter-to-crofter mutual aid rather than for-profit seed production. The seed itself is traded as it is grown: as a mixture, pivotal to keeping the entire livestock rearing system feasible. The seed, as the source of home-grown fodder, reduces the cost of imported silage, as observed by crofter Angus Laing in It's In the Blood, a 2018 BBC documentary on crofting on South Uist. Furthermore, there is a regional ethos based on seed saving as community service in the face of economic necessity. This ethos can be seen as a form of mutualism to support the precarious island crofting life, sometimes still 
through barter, in the knowledge that this is a unique seed system. Part of the ethos is locals' pride in producing 'a good clean seed crop', similar to that observed among the Northern Isles crofters on Orkney and Shetland in Mahon's study (2016).

In recent decades seed growing, once a feature of every crofting township, has become more precarious. Fewer crofters are involved due to a combination of increased pressure on seed supply by pest species such as geese and deer, fewer hands (beyond demographic shifts, there is a lack of local employment and housing to retain younger locals), declining knowledge and experience and a narrower harvesting window due to the impacts of climate change.

Research on Orkneybere barley has contributed significantly to its preservation on Orkney, but prior to the present project, no similar work had been done on Hebridean rye. The local threats make research on the Uist landraces more urgent, as opening up new value chains for landraces can contribute to their preservation as well as create crucial income opportunities. The latter are vital not just for young crofters but also for entrepreneurs such as the team behind the North Uist Distillery, who are keen to build on island crofting traditions. The distillery's founder and artistic director Kate MacDonald has written on their website that they are 'proud to be able to promote a new generation of croftingproviding people with a reason to grow the island's trademark organic bere barley', the most successful Scottish landrace (Hordeum vulgare). These emerging, often micro- or social enterprises, are seen as vital to turning the demographic tide on Uist (Fisher \& Morrison, 2019).

Adding value to traditional varieties has succeeded on Orkney both with bere, and with traditional Scottish wheats (Whitley, 2019), through the development of value chains for flour and beverages, and assessments of the flours' nutritional profile (Theobald et al., 2006). The ongoing work on bere on Orkney has become a model for other areas, new distilleries on the Inner Hebridean island of Raasay, for instance, and has inspired the present Uist project.

Scotland's traditional cuisine does not feature rye bread, despite the popularity of rye in nearby Nordic nations. Although commonly grown at scale in other countries such as Germany, Poland and Estonia, it is currently only grown on a small scale in Scotland. The name 'Hebridean rye' requires some explanation. When rye samples were collected in 2009 as part of gene-bank conservation of Scottish landraces (Scholten et al., 2009), the samples were deposited at Science and Advice for Scottish 
Agriculture (SASA) in Edinburgh under the name Hebridean rye. From that time, the Uist rye landrace was referred to thus, in addition to its vernacular Gaelic name, seagal. Scottish Gaelic is still the dominant language over much of the Outer Hebrides and remains common as the working language of crofters.

The Gaelic names of the other two cereal landraces passed down and still in use are for oats (Avena strigosa) either coerce or coirce beag, while for bere (Hordeum vulgare) is eorna. Both names have an inherent distinction from seeds from the mainland. 'Coirce mor' and 'mainland barley' for other barley varieties. A recent example of the vernacular use of landrace names can be heard in the documentary Crofting and the Uist Machair (Farming Advisory Services, 2019), in which North Uist crofter Donald John MacDonald notes: 'We sow what we call coirce beag and sometimes some rye'.

\subsection{Lochaber's Demand For New Rye Landraces}

Rye is currently growing in both recognition and popularity in Scotland. An increasing number of small and artisanal bakers are interested in traditional and landrace varieties of cereal that may not necessarily suit large-scale processing, but provide the opportunity for a more flexible and innovative approach to the use of flour mixes and bakery products. In recent years, craft brewing and distilling have seen significant growth in Scotland, with small-scale producers satisfying increasing public demand for diversity within the market, and rural and island breweries and distilleries seeking new ingredients that help them to connect with their local environment and heritage, or that have an interesting story to tell and sell.

One of the crofters involved in the project, Adam Veitch, is developing his existing commercial micro bakery into a 'seed to loaf' peasant model of bakery with rye grown on local crofts within Lochaber, near Fort William in the Highlands (Veitch \& Veitch, undated) A rye trial was proposed to explore the potential of different varieties and in particular Hebridean rye for growing in the Lochaber area on the Scottish mainland, and to assess its potential in rye breads and other baked products.

There is a burgeoning interest in local food in Lochaber, and a new ethos in supporting the re-emergence of a local food economy. It is partly driven by tourism, but also by local growers and consumers, and organisations such as the Lochaber Environmental Group and Food Lochaber, 
a collective of local producers that are devoted to production informed by organic principles and crofting practice. Lochaber is not a locale associated with farming traditions. Grain growing has largely disappeared over the last century deforestation has led to soil degradation (Wombell, 2003), predatory deer numbers are rising and a lack of grain-specific machinery and know-how have made reintroducing cereal growing very challenging.

However, the factors detailed in this chapter-the survival of an unexplored rye landrace on Uist, and the search for new rye landraces on the mainland-inspired the Crofters' Diversity Pays! (CDP) project. This initially lasted a year (May 2019-April 2020), but remains ongoing to date because of the covid-19 pandemic.

\subsection{Project Aims and Research Questions}

Under the CDP project, researchers have examined potential income streams for crofters through the assessment of new uses for traditional landrace varieties they grow, many maintained over generations as a unique form of agricultural biodiversity. Developing new uses and highend products from low-value agricultural assets can provide new business opportunities for crofters and develop new markets for their produce which, in turn, can help both maintain and reinvigorate a traditional way of life.

The project aimed to undertake research in a crofting context, with crofters involved in the investigation, and also as beneficiaries, by assessing the potential value of a neglected landrace for a potentially new growing area.

The aim of the rye workstream was to investigate the potential to add value to Hebridean rye in order to inform crofters and food and drink producers of the potential uses of the cereal as a new and unique ingredient in a number of artisan products. The research questions included the following:

- How does Hebridean rye compare with other varieties of rye as regards its suitability for a mainland grain-to-loaf value chain

- What kind of processing can be used to transform Hebridean rye into food and drink products?

- How might the introduction of Hebridean rye be leveraged to create a local grain supply for food and drink production? 
- Does the rye have special nutritional value, does it taste good and will people eat it?

- What end-use food and drink products might be produced using the rye?

- How might these Hebridean rye products be branded and marketed?

\subsubsection{The Chosen Locations}

In the course of the project, the Hebridean rye seed grown in Uist was introduced in Lochaber. As a consequence, issues of continuity, and discontinuity, of tradition and values related to seed arose between the two locations.

Uist and Lochaber can be seen as representing two approaches to contemporary crofting practice. On the one hand is the long-established Outer Hebridean traditional crofting mode of agriculture, an island practice based on a livestock rearing system; local seed sources are intact, and it is run by mostly primary producers selling to mainland markets, in a linear model with very long chains. On the other hand is a mainland Highlands practice emerging where cereal growing and local seed sources have disappeared, and where groups of collaborators organise direct sales for crops and meat using agroecological practices and ethos. The general attitude on the mainland is that reintroduction of locally grown grain will be both challenging but ultimately beneficial.

In both locations, producers sought collaborations with local processors who might be interested in developing new products from Hebridean rye. Results of the research were also published in local newspapers in both locations.

\subsubsection{The Growing Trial in Lochaber}

A number of rye varieties were sourced as comparison varieties for benchmarking against the Hebridean rye and also with a view to building a rye nursery in Lochaber with a wider range of varieties. The ultimate goal was to create a locally adapted and evolving rye population that would yield enough grain for a local micro bakery as well as provide a model for other growers and micro producers In addition, participants running the rye nursery formed observation learning material for the crofters to begin to communicate and restore the know-how of growing grain in Lochaber. 
Both summer and winter varieties were sourced and tested, despite there being no recorded history of growing winter cereals in this part of the Highlands. This may have been due to the arable fields being used for winter grazing.

During the 2019 summer growing season at the croft nursery, three different rye varieties were grown: Hebridean rye, a commercial variety and a landrace originating from Scandinavia. During the 2019/2020 winter, another five varieties were tested: one Baltic, three Scandinavian, a mixed population sourced through the collaborative project Scotland the Bread and a traditional German bread rye.

The Hebridean rye was found to be suitable for growing in Lochaber, and to have some useful attributes as a crop that may work well in developing an evolutionary cereal rye population for the area (Veitch \& Scholten, 2020). However, overall, the winter rye varieties outperformed the summer varieties on both weed suppression and yield.

This growing trial was an important strand of the overall project, exploring the pathway from seed to harvest and providing practical insight from the perspective of the crofter that grew the crop. And, beyond the more specific narrow aim, it was key in building genetic resources, the knowledge and experience of growing rye, and an acquaintance with different rye varieties and their suitability for Lochaber growing conditions.

\subsubsection{Sensory Qualities, Nutritional Value and Product Testing}

The Hebridean rye was tested to ensure that levels of ergot and other pathogens were safe, and that it was of high quality. Artisanal bakers were recruited to test its milling properties and viability for baking; craft brewers explored its suitability for brewing. All results were positive, confirming that the rye is suited to small-scale flour production, artisan baking and the production of craft alcohol products.

Other research has suggested that traditional or landrace crops can have higher nutritional value than modern cultivars. This was the first research to report the nutritional properties of Hebridean rye, revealing that it contained high levels of many useful micro- and macro-nutrients and had potential for use in healthy food products, and as an added ingredient to fortify other foods. The rye was found to be high in fibre and protein; it also contained significant levels of phosphorus, manganese and zinc, and has a diverse mineral composition overall. 
A number of prototype and test breads and beers were produced at the Lochaber-based 'Doughies' and 'Grain of Truth' bakeries. Initial results from a series of consumer tasting panels undertaken through the MSc Gastronomy department at Edinburgh's Queen Margaret University suggested that the products had a distinctive and enjoyable flavour profile and that consumer acceptance levels were high, suggesting that people would buy products containing Hebridean rye.

Branding and packaging inevitably influence consumer choices. Initial discussions suggested that there was significant potential for marketing products containing Hebridean rye, and that the stories behind its nutritional qualities, scale of production, crofting heritage, Gaelic connections and specific provenance and terroir would be key to the process.

\subsection{Conclusions}

This was the first investigation into the qualities of the rye landrace from Uist, and potential products derived from it. The research had an artisan crofting-baking business as starting point and developed into a partnership of academic researchers, food processors, small-scale food and drink producers, and established new links between crofters across remote areas in the Highlands and Islands of Scotland. The research has been vital to understanding the journey towards marketable products based on Hebridean rye, which, if developed, could ensure its viability as a crofting crop along with that of other traditional landraces.

One of the first and unintended outcomes of the research was that from the very start it showed how little known the existence of a local Scottish rye was, even in its Outer Hebridean place of origin. Outside that region, few growers and processors were aware of it, although Scotland has recently seen strong interest in rye as an ingredient for baked goods and alcoholic drinks. This confirmed the importance of research into rye as an underutilised crop and, more generally, the need to foster more awareness of local Scottish varieties of rye.

Secondly, the growing trial looked into the potential of Hebridean and other rye landraces as a crop for agroecological crofting in a new environment and as a new seed source. Trials such as these-which take place outside agricultural institutions, focus on minor crops and are led by farmers working at a small scale in marginal growing areas-need further support. Such approaches are more common on the European continent. The similar but much larger Diversifood project, and agricultural 
biodiversity networks such as Let's Liberate Diversity, ${ }^{1}$ were consulted as models for this project.

Regarding seed governance and ethos, there seemed to be much in common between the Hebridean informal ad hoc seed supply based on a mutual support ethos and the new location in Lochaber. As Adam Veitch noted on plans for his growing programme, the rye "needs to go on a bulking up exercises the next few seasons, both for ourselves and to share/distribute to others. I'd love this to be open source but it also needs to be sustainable'. His plan is to create a rye population hefted to an area, evolving and becoming its own locally adapted grain, rather than strict adherence to the Hebridean rye cultivar.

This groundbreaking research project has provided information that can be utilised to provide new business opportunities for crofters and to develop new markets for their produce. It started investigating each step in the value chain of Hebridean rye from croft-grown rye as input for a micro-artisan bakery and several beverages. The research uncovered various solutions to the lack of machinery and equipment needed to sort, clean, and dry seeds. Based on their own agricultural needs, crofters innovate by constructing their own machinery using engineering skills and traditional knowledge. Access to commercial or laboratory seed cleaning machinery is limited and costly. The research identified the need for machinery infrastructure at each step in the value chain, both in its original and new location.

Hebridean rye has the potential to play a valuable role in Scotland's food and drink industry, providing business opportunities for those living in remote and rural areas, allowing the diversification of supply chains and potentially even impacting positively on dietary health. An added benefit is the positive impact that this could have on the preservation of agricultural biodiversity and the traditional knowledge and practices associated with the cultivation of Hebridean rye.

Acknowledgements Crofters on Uist are warmly thanked for their time, seeds and advice. Andrew Whitley (Scotland the Bread) for advice, seeds and data. Anders Naess of Specialkorn in Norway, Annika Michaelson of Mustiala Agricultural School in Finland, and the Estonian Crop Research Institute for making seeds available.

$1_{\text {www.liberatediversity.org }}$ 


\section{REFERENCES}

Diversifood project. www.diversifood.eu. Accessed July 25, 2021.

Farming Advisory Services. (2019). Crofting and the Uist Machair. Video documentary. Retrieved December 15, 2020, from https://www.youtube.com/ watch? $\mathrm{v}=\mathrm{m} 7 \mathrm{MP0D} 2 \mathrm{YyDU}$

Fisher, T., \& Morrison, T. (2019). Turning the tide on Uist. Webblog Islands Revival. CoDeL. Retrieved July 25, 2021, from https://islandsrevival.org/ turning-the-tide-on-uist/

Let's Liberate Diversity. https://liberatediversity.org/ as Accessed July 25, 2021.

Mahon, N., McGuire, S., \& Islam, M. M. (2016). Why bother with bere? An investigation into the drivers behind the cultivation of a landrace barley. Journal of Rural Studies, 45, 54-65. https://doi.org/10.1016/j.jrurstud. 2016.02.017

Martin, M. (1703). A description of the Western Isles of Scotland circa 1695 (1999 ed.). Birlinn Press.

North Uist Distillery Co. website (undated). https://www.northuistdistillery. com/. Accessed July 25, 2021.

Schmidt, S. B., George, T. S., Brown, L. K., Booth, A., Wishart, J., Hedley, P. E., Martin, P., Russell, J., \& Husted, S. (2019). Ancient barley landraces adapted to marginal soils demonstrate exceptional tolerance to manganese limitation. Annals of Botany, 123, 831-843. https://doi.org/10.1093/aob/mcy215

Scholten, M., Spoor, C., \& Green, N. (2009). Machair corn: Management and conservation of a historical machair component. The Glasgow Naturalist, 25, 63-71. Supplement: machair conservation: successes and challenges.

Theobald, H. E., Wishart, J. E., Martin, P. J., Buttriss, J. L., \& French, J. H. (2006). The nutritional properties of flours derived from Orkney grown bere barley (Hordeum vulgare L.). Nutrition Bulletin, 31(1), 8-14. https://doi. org/10.1111/j.1467-3010.2006.00528

UHI. https://www.uhi.ac.uk/en/research-enterprise/res-themes/silk/agr onomy-institute/research-on-cereals/

Veitch, A., \& Scholten, M. (2020). Rye nursery technical report. Unpublished report as part of final report of the CDP! Project to the Scottish government.

Veitch, A., \& Veitch, A. (undated). Doughies. Retrieved July 25, 2021, from www.doughies.blog

Ward, C. (1988). Anarchy in action. Freedom Press. (Reprint from 1973 first edition).

Whitley, A. (2019). The nutritional profiles of heritage wheat and rye varieties grown by Scotland The Bread in 2018. Scotland The Bread. Unpublished.

Wombell, J. (2003). The spirit of the soil: An historical perspective on soil fertility and the application of composting in Lochaber. Lochaber Environmental Group. 
Wood, B. (2018). San Fhuil/It's in the Blood. Documentary. TrixPixMedia. Retrieved July 24, 2021, from BBC ALBA website. https://www.bbc.co.uk/ programmes $/ \mathrm{m} 0001 \mathrm{bdf}$

Open Access This chapter is licensed under the terms of the Creative Commons Attribution 4.0 International License (http://creativecommons.org/licenses/ by $/ 4.0 /)$, which permits use, sharing, adaptation, distribution and reproduction in any medium or format, as long as you give appropriate credit to the original author(s) and the source, provide a link to the Creative Commons license and indicate if changes were made.

The images or other third party material in this chapter are included in the chapter's Creative Commons license, unless indicated otherwise in a credit line to the material. If material is not included in the chapter's Creative Commons license and your intended use is not permitted by statutory regulation or exceeds the permitted use, you will need to obtain permission directly from the copyright holder.

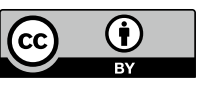

